\title{
Uzaktan Eğitim ve Uzaktan Öğretmen Yetiştirme Bağlamında Akademisyen Uygulama, Görüş ve Önerileri
}

\section{Umut ÇARDAK* ve Çetin GÜLER**}

Öz: Bu araştırma Covid-19 Pandemisi ile birlikte zorunlu ve ani bir biçimde uygulamaya geçilen acil uzaktan eğitim sürecinde, eğitim fakültelerinde ders veren akademisyenlerin acil uzaktan eğitim uygulamaları, bu süreçte karşılaştıkları sorunlar ile bunlara karşı çözüm önerileri ile uzaktan eğitime dair genel görüşleri ve bu görüşlerde pandemi sonrası ne tür değişimler olduğuna ilişkin bilgi toplamayı amaçlamaktadır. Araştırma, nitel araştırma yöntemlerinden durum çalışması ile yürütülmüştür. Veriler araştırmacı tarafından geliştirilen yarı-yapılandırılmış görüşme formu aracılığı ile toplanmıştır. Araştırmanın katılımcı grubunu eğitim fakültelerinde farklı bilim dallarında görev yapan uzaktan eğitim yoluyla ders veren on akademisyen oluşturmaktadır. Görüşmeler video-konferanslar aracılığıyla yapılmış ve bu görüşmeler kayıt altına alınmıştır. Elde edilen veriler betimsel analiz ve içerik analizi ile çözümlenerek çok sayıda bulguya ulaşılmıştır. Elde edilen bulgular alanyazındaki diğer bazı çalışmalar ışı̆̆ında tartışılmış ve uzaktan öğretmen yetiştirmede yer alan paydaşlara çeşitli önerilerde bulunulmuştur.

Anahtar Kelimeler: Uzaktan Eğitim, Acil Uzaktan Eğitim, Uzaktan Öğretmen Yetiştirme, Akademisyen Görüşleri.

\section{Academicians' Practices, Opinions and Suggestions in The Context of Distance Education and Distance Teacher Training}

Abstract: In the period of emergency remote education which was implemented suddenly and compulsory due to the Covid-19 pandemic, the aim of this study is to collect information about the way in which academicians who teach in faculties of education apply the distance education model, the problems they encounter and the solutions they produce against them, their general views and what changes have occurred in these views after the

\footnotetext{
*Yüksek Lisans Öğrencisi, Van Yüzüncü Y1l Üniversitesi, Eğitim Bilimleri Enstitüsü, Email: umutcrdk@gmail.com, Orcid No: 0000-0003-4366-5179

** Doç. Dr. Van Yüzüncü Y1l Üniversitesi, Eğitim Fakültesi, Bilgisayar ve Öğretim Teknolojileri Eğitimi Bölümü, Email: cetin@yyu.edu.tr, Orcid No: 0000-0001-6118-9693
} 
pandemic. The research was conducted with a case study, one of the qualitative research methods. Data were collected through a semi-structured interview form developed by the researcher. The participant group of the research consists of ten academicians who teach through distance education in faculties of education. The interviews were made via videoconferences and these interviews were recorded. Many findings were obtained by analyzing the obtained data with the methods of descriptive analysis and content analysis. The findings were discussed in the light of some other studies in the literature and various suggestions were made to the stakeholders involved in distance teacher training.

Keywords: Distance Education, Emergency Distance Education, Distance Teacher Training, Academic View

\section{Giriş}

Bilgi ve iletişim teknolojilerindeki (BİT) gelişmeler, yaşamın birçok alanında olduğu gibi eğitim alanında da yeni yaklaşım ve modellerin oluşmasında rol oynamıştır (Roberts, 2015). Bu gelişmelere bağlı olarak geleneksel eğitim yaklaşımlarına alternatif veya destekleyici olan bilgisayar destekli eğitim, web tabanlı eğitim, harmanlayıcı öğrenme, mobil öğrenme, e-öğrenme, çevrimiçi öğrenme ve uzaktan eğitim (UE) gibi birçok model - öğretim yöntemi ortaya çıkmıştır (Naidu, 2006). Sayılan bu modeller ve yöntemler arasında bazı nüans farklılıkları bulunsa da en geniş ve diğerlerinin tamamını kapsayan eğitim modeli UE'dir (Demir, 2015; Kırık, 2014; Urdan ve Weggen, 2000).

Farklı tanımlamaları bulunan UE; en genel anlamıyla öğreten ve öğrenenin aynı mekânda bulunmak zorunda olmadığı ve eğitim-öğretim etkinliklerinin BİT sayesinde yürütüldüğü eğitim modelidir (İşman, 2011). Tarihsel gelişimi incelendiğinde ilk uygulamaları mektupla öğretim biçiminde başlayan UE'ye ilişkin özellikler ve tanımlamalar, kullanılan teknolojik gelişmelere bağlı olarak değişmektedir. Özellikle bilgisayarların ve internetin yaygınlaşması sonucu UE yeni bir boyut kazanmış ve "İnternet Tabanlı UE" kavramı eğitim alanyazınında yerini almıştır (Naidu, 2006). İnternet altyapısının kullanıldığı bu modelde geleneksel postanın yerini alan e-postalar, basılı materyallerin yerine kullanılan ve alternatif görevi gören elektronik kaynaklar, çift yönlü etkileşim sağlayan video konferans görüşmeleri ve Öğrenme Yönetim Sistemleri (ÖYS) gibi bazı unsurlar görülür (Ekinci, 2015; Pektekin, 2013). Bu çerçevede günümüz koşullarında UE; zamandan ve mekândan bağımsız biçimde, var olan teknolojik imkanlar aracılığıyla sürdürülebilen, sanal ortamda yazılı, sesli veya görüntülü olarak derslerin işlenebildiğgi, katılımcıların istediği zaman bu dersleri tekrar izleyebileceği güncel bir eğitim modeli olarak tanımlanabilir (Clark, 2020; Orakçıŏlu, 2019). 
UE’nin yüz yüze eğitime kıyasla bazı üstünlükleri vardır. Büyük kitlelere hitap edebilme, zaman ve yer yönünden sınırlama olmaması, bireysel öğrenme özelliklerine göre uyarlanabilmesi, çoklu ortam araçlarının kullanımı, daha fazla duyu organına hitap edebilme ve zorunlu durumlarda kullanılabilecek bir model olması UE’nin en önemli artıları arasında sayılabilir (Karakuş, Ucuzsatar, Karacaoğlu, Esendemir ve Bayraktar, 2020; Keegan, 1996; Sayan, 2020). UE’nin birçok üstünlüğü bulunmasına rağmen; teknik sorunların muhtemel olması, uygulamalar için gerekli altyapı ve teknik araç-gereç maliyetlerinin yüksek olması, yüz yüze eğitim ilişkilerinin yeterince sağlanamaması, hem eğitici hem öğrenci için belirli bir hazır bulunuşluk gerektirmesi ve uygulamalı dersler için verimli olmaması gibi bazı sınırlılıkları da mevcuttur (Bates ve Bates, 2005; Çağıltay vd., 2007; İşman, 2011; Z. Kaya, 2002). Geçmişten günümüze UE’nin genel özellikleri, geçirdiği evreler, üstünlükleri ve sınırlılıkları gibi konular sıkça tartışılmakla birlikte; günümüzde UE, Covid-19 pandemisi ile birlikte tüm dünyada olduğu gibi Türkiye'de de ani ve topyekün bir şekilde uygulanmaya başlandığından bir acil durum eğitimi niteliği kazanmıştır.

Aralık 2019'da ilk olarak Çin-Wuhan'da tespit edilen Coronavirüs (Covid-19), kısa süre içinde çok sayıda insana bulaşarak onları hasta etmiş ve çok sayıda ölüme neden olmuştur. Dünya Sağlık Örgütünce (WHO) küresel bir pandemi olarak duyurulmuş, başta sağlık alanı olmak üzere yaşamın her alanında önemli etkilere neden olmuştur (WHO, 2020). Covid-19 pandemisi, dünya genelinde eğitim sistemlerini de etkilemiş, yaygın bir biçimde tüm eğitim kurumlarının yüz yüze eğitimi durdurmalarına sebep olmuştur (Wikipedia, 2020). İnsanların en temel haklarından biri olan eğitim - öğretim faaliyetlerinin yürütülememesi karşısında UE uygulamaları küresel çapta temel bir çözüm olarak gündeme gelmiştir (UNESCO, 2020). Tüm bu gelişmeler Acil Uzaktan Eğitim (AUE) adı verilen yeni bir kavramın ortaya çıkmasına zemin hazırlamıştır (Hodges, Moore, Lockee, Trust ve Bond, 2020).

Pandemi sürecinde devam ettirilen AUE faaliyetleri geleneksel UE etkinliklerine benzer biçimde görülmesine karşın, ikisi arasında bazı farklar bulunmaktadır (Bozkurt ve Sharma, 2020; Hodges vd., 2020) Öne çıkan farklılıklardan biri planlama boyutu ile ilgilidir. Geleneksel UE etkinlikleri uzun ve detaylı bir planlama sürecine sahipken pandemi döneminde yürütülen AUE planlamaları ve alınan kararlar hızlı bir biçimdedir (Yavuz, Kayalı, Balat ve Karaman, 2020). Ayrıca geleneksel UE ile öğrenmenin gerçekleştirilmesi amaçlanırken, pandemi sürecinde gerçekleştirilen AUE ile öğretim faaliyetlerinin devam ettirilmesi ve öğrencilerin süreçten kopmamaları amaçlanmıştır. Birçok araştırmacıya göre bu; 
belirli bir kriz durumuna yanıt olarak geliştirilen alternatif, geçici bir öğretim yöntemidir (Shim ve Lee, 2020). Bu süreçteki ilk amaç, aksayan eğitsel etkinliklere acil-geçici çözümler oluşturabilmektir (Hodges vd., 2020). Bu acil-geçici çözümler, öğreten ve öğrenenleri çeşitli çevrimiçi araçlar yardımıyla hızlı bir biçimde bir araya getirme refleksi olarak ifade edilebilir. $\mathrm{Bu}$ bağlamda araştırmanın geri kalanında pandemi döneminde uzaktan yürütülen öğretim etkinlikleri için AUE kavramı kullanılacaktır.

İlk Covid-19 vakasının ülkede görülmesinden itibaren (T.C. Sağlık Bakanlığı, 2020), Türkiye'de Milli Eğitim Bakanlığı'na (MEB) bağlı okullarda yüz yüz eğitime 16 Mart 2020 gününden sonra üç hafta ara verilmiş, eğitim - öğretim faaliyetlerin "EBA TV” televizyon kanalları ve Eğitim Bilişim Ağı (EBA) üzerinden sürdürülmesi kararı alınmıştır (MEB, 2020). Covid-19 pandemisi sebebiyle, yükseköğretim kurumlarında da 12 Mart 2020'de yüz yüze eğitime ara verilmiş, Yükseköğretim Kurulu (YÖK) tarafından 23 Mart 2020 gününden itibaren 2019-2020 öğretim yılı bahar döneminin UE ile sürdürüleceği açıklanmıştır (YÖK, 2020). Böylece Türkiye' de bir "kriz durumu nedeniyle" ilk defa 2020 Elazığ depreminde aktif olarak deneyimlenen UE (Can, 2020), günümüzde Covid-19 pandemisi ile birlikte daha kapsamlı bir biçimde tüm öğretim kademelerinde tecrübe edilmeye başlanmıştır.

Her ne kadar daha önceden Türkiye'de UE kapsamında bazı üniversitelerde, özellikle “ortak zorunlu derslerin” yürütülmesi şeklinde bazı uygulamalar olsa da; bu denli ani bir biçimde, ulusal düzeyde ve tüm kurumlarla eğitimin uzaktan sürdürülmesi pandemi sürecinde ilk kez karşılaşılan bir durum olmuştur (Kurnaz ve Serçemeli, 2020). Birçok öğrenci, öğretmen, veli, akademisyen vb. eğitim paydaşları UE ile bu süreçte tanışmışlardır (Durak, Çankaya ve İzmirli, 2020; Kırmızıgül, 2020). Bu durum UE’nin önceki dezavantaj ve sınırlıklarının yanında tüm paydaşları etkileyen birçok sorunun doğmasına yol açmıştır.

Covid-19 sürecinde yapılan araştırmalarda; AUE'nin uygulamalı derslere uygun olmaması (Kahraman, 2020; Keskin ve Özer Kaya, 2020; Kurnaz ve Serçemeli, 2020; Shim ve Lee, 2020), üniversitelerin alt yapısındaki sorunlar, iletişim - etkileşim eksikliği (Çakın ve Külekçi Akyavuz, 2020), maddiyat kaynaklı erişim sorunu, pandeminin getirdiği duygu durum ve sınav kaygısı (Kürtüncü ve Kurt, 2020), internet bağlantısında yaşanan sorunlar, öğrencilerin derslere katılım oranının düşük olması (Mhlanga ve Moloi, 2020; Zan ve Zan, 2020), okul yönetiminin baskısına maruz kalma (Bakioğlu ve Çevik, 2020), sosyalleşmeyi kısıtlaması (Başaran, Doğan, Karaoğlu ve Şahin, 2020), öğrenenlerin yeterince öğrenme sorumluluğu alamaması ve ölçme-değerlendirme süreçlerinde yaşanan sorunlar (Bozkurt, 2020) bu dönemde öne çıkan bazı olumsuzluklardır. Bunun yanında üniversitelerde birçok 
akademisyen için UE uygulamaları deneyim açısından yeni bir süreç olduğundan, akademisyenlerin de çeşitli sorunlarla karşılaşması muhtemeldir (Bozkurt ve Sharma, 2020; Gürer, Tekinarslan ve Yavuzalp, 2016; Kaysi, 2020). Zaten pandemi öncesinde de Türk Yükseköğretiminde istenilen düzeyde ve etkinlikte BİT kullanılmadığı ve akademisyenlerin derslerinde BİT kullanım konusunda yeterli bilgi-beceriye sahip olmamaları eleştirilen durumlardandır (Sadi vd., 2008). Bu durumun pandemi sürecinde de devam edip etmediği, akademisyenlerin pandemi sürecindeki AUE uygulamaları, karşılaştıkları sorunlar ve bu sorunlara yönelik çözüm önerileri ile AUE’ye olan görüşleri ortaya konularak mevcut durumun iyileştirilmesine katkı sunulabilir.

Alanyazında UE ile ilgili araştırmaların çoğunlukla nicel yaklaşım ile yürütüldüğü, nitel veya karma araştırmaların ise sınırlı sayıda olduğu görülmektedir (Horzum, Özkaya, Demirci ve Alpaslan, 2013). Nitel araştırmalar olayların ve durumların daha derinlemesine olanak tanıyan bir yaklaşımla yürütülmektedir (Glesne, 2013). Bu doğrultuda; AUE süreçlerinde öğretmen yetiştirme sorumluluğu bulunan eğitim fakültesi akademisyenlerinin bu süreçteki uygulama ve görüşlerine dair derin bir incelenme yapılmasının alanyazına katkıda bulunacağı değerlendirilmektedir.

Bu çalışmayla; Covid-19 Pandemisi ile birlikte zorunlu ve ani bir biçimde uygulamaya geçilen AUE sürecinde, eğitim fakültelerinde ders veren akademisyenlerin UE/AUE ve uzaktan öğretmen yetiştirme (UÖY) ile ilgili görüşleri, AUE uygulamaları, bu süreçte karşılaştıkları sorunlar ile bunlara karşı çözüm önerilerine dair bilgi toplamak amaçlanmıştır.

\section{Araşturma Problemi}

Eğitim fakültelerinde görev yapan akademisyenlerin; Covid-19 pandemisi döneminde AUE uygulamaları, AUE sürecinde karşılaştıkları sorunlar ve bu sorunlar için çözüm önerileri ile AUE/UE ve UÖY'ye yönelik görüşleri nelerdir?

\section{Alt problemler.}

1- Akademisyenlerin Covid-19 öncesi UE deneyimleri nasıldır?

2- Akademisyenler AUE sürecinde hangi sorunlarla karşılaşmaktadırlar?

3- AUE sürecinde karşılaşılan sorunlara karşı akademisyenler neler önermektedirler?

4- Akademisyenlerin UÖY'ye ilişkin görüşleri nelerdir?

\section{Yöntem}

\section{Araştırmanın Deseni}

$\mathrm{Bu}$ araştırmada nitel araştırma yöntemlerinden durum çalışması modeli kullanılmıştır. A. Yıldırım ve Şimşek’e (2003) göre nitel araştırma; algıların ve olayların doğal ortamda 
gerçekçi ve bütüncül bir biçimde ortaya konmasına yönelik nitel bir sürecin izlendiği araştırma olarak tanımlanmaktadır. Akademisyenlerin deneyimlerine bağlı biçimde bilgi alınabilmesi ve olayların kendi doğal bağlamları içerisinde incelenebilmesi amacıyla bu yöntem tercih edilmiştir.

\section{Çalışma Grubu}

Araştırmanın çalışma grubunu çeşitli üniversitelerin eğitim fakültelerinde görevli, AUE sürecinde öğretim sürdüren 10 akademisyen oluşturmaktadır. Araştırmada çalışma grubunun belirlenmesinde amaçlı örnekleme yöntemlerinden biri olan ölçüt örnekleme kullanılmıştır. Ölçüt örnekleme yönteminde de araştırmacı önceden belirlediği kriterler doğrultusunda örneklem birimini seçer. Araştırmanın amacı ve alt problemler doğrultusunda bu çalışmanın katılımcıları belirlenirken akademisyenlerin;

- Eğitim fakültelerinde görev yapıyor olması,

- Pandemi sürecinde AUE ile öğretim sürdürüyor olması,

ölçütleri esas alınmıştır. Ancak Türkiye çapında eğitim fakültelerinde görev yapan tüm akademisyenlere ulaşılması mümkün olmadığından, erişilebilir tüm katılımcılar e-posta veya telefon yoluyla davet edilmiştir. Davet edilen katılımcılardan olumlu yanıt alınanlardan öncelik sırasına göre görüşmelere başlanmıştır. Katılımcılar görüşülme sırasına göre K1, K2, $\mathrm{K} 3 \mathrm{vb}$. şeklinde isimlendirilmiştir. Yapılan her görüşme sonrası toplanan veriler analize tabi tutulmuştur. Toplanan veriler birbirini tekrar eder hale gelerek yeterli doygunluğa ulaştığında veri toplama süreci sonlandırılmıştır. Çalışma grubuna dair bazı demografik bilgileri Tablo 1 'de sunulmuştur.

Tablo 1. Katılımcıların Demografik Bilgileri

$\begin{array}{lll}\text { Üni. Bölüm } & \text { Unvan } & \begin{array}{l}\text { Mesleki } \\ \text { Deneyim }\end{array}\end{array}$

\begin{tabular}{|c|c|c|c|c|}
\hline K1 & $\begin{array}{l}\text { İzmir } \\
\text { Demokrasi } \\
\text { Üni. }\end{array}$ & $\begin{array}{l}\text { Temel Eğitim Bölümü/Sınıf Eğitimi } \\
\text { A.B.D. }\end{array}$ & Doç. Dr. & 35 Y11 \\
\hline K2 & $\begin{array}{l}\text { Mehmet Akif } \\
\text { Ersoy Üni. }\end{array}$ & $\begin{array}{l}\text { Türkçe Ve Sosyal Bilimler Eğitimi } \\
\text { Bölümü / Sosyal Bilgiler Eğitimi } \\
\text { A.B.D. }\end{array}$ & Prof. Dr. & 37 Y11 \\
\hline K3 & $\begin{array}{l}\text { Van Yüzüncü } \\
\text { Y11 Üni. }\end{array}$ & $\begin{array}{l}\text { Güzel Sanatlar Eğitimi Bölümü / } \\
\text { Resim-İş Eğitimi A.B.D. }\end{array}$ & Dr.Öğr.Üyesi & 11 Y11 \\
\hline K4 & $\begin{array}{l}\text { Van Yüzüncü } \\
\text { Y11 Üni. }\end{array}$ & $\begin{array}{l}\text { Orta Öğretim Fen ve Matematik } \\
\text { Alanları Eğitimi Bölümü / Biyoloji }\end{array}$ & Dr.Öğr.Üyesi & 27 Y11 \\
\hline
\end{tabular}


Eğitimi A.B.D.

$\begin{array}{lllll}\text { K5 } & \begin{array}{l}\text { Bursa Uludağ } \\ \text { Üni }\end{array} & \begin{array}{l}\text { Spor Bilimleri / Beden Eğitimi ve } \\ \text { Spor Öğretmenliği Bölümü }\end{array} & \text { Doç. Dr. } & 30 \text { Yıl } \\ \text { K6 } & \begin{array}{l}\text { Van Yüzüncü } \\ \text { Y11 Üni. }\end{array} & \begin{array}{l}\text { Güzel Sanatlar Eğitimi Bölümü / } \\ \text { Müzik Eğitimi Anabilim Dalı }\end{array} & \text { Dr.Öğr.Üyesi } & 8 \text { Y1l } \\ \text { K7 } & \begin{array}{l}\text { Bursa Uludağ } \\ \text { Üni }\end{array} & \begin{array}{l}\text { Güzel Sanatlar Eğitimi Bölümü / } \\ \text { Müzik Eğitimi Anabilim Dalı }\end{array} & \text { Doç. Dr. } & 30 \text { Y1l } \\ \text { K8 } & \begin{array}{l}\text { Bursa Uludağ } \\ \text { Üni }\end{array} & \begin{array}{l}\text { Türkçe Ve Sosyal Bilimler Eğitimi } \\ \text { Bölümü/Türkçe Eğitimi Anabilim Dalı }\end{array} & \text { Doç. Dr. } & 30 \text { y1l } \\ \text { K9 } & \begin{array}{l}\text { Mehmet Akif } \\ \text { Ersoy Üni. }\end{array} & \begin{array}{l}\text { Eğitim Bilimleri Bölümü / Eğitim } \\ \text { Programları Ve Öğretim Anabilim }\end{array} & \text { Prof. Dr. } & 35 \text { yıl } \\ & & \text { Dalı } & & \end{array}$

K10 Marmara Üni. Matematik ve Fen Bilimleri Eğitimi $\quad$ Prof. Dr. $\quad 27$ Y11 Bölümü / Fizik Eğitimi Anabilim Dalı

Tablo 1'de görüldüğü üzere araştırmaya beş farklı üniversiteden, dokuz farklı programda görevli, en düşügü sekiz, en yükseği 37 yıllık deneyime sahip on akademisyen katılmıştır. Bunların üçer kişisi Prof. Dr. ve Dr. Öğr. Üyesi, dördü ise Doç. Dr. unvanına sahip akademisyenlerdir.

\section{Veri Toplama Süreci}

$\mathrm{Bu}$ araştırma yarı yapılandırılmış görüşme tekniği ile yürütülmüştür. Veriler araştırmacı tarafından geliştirilen veri toplama aracı ile elde edilmiştir. Görüşmeler, pandemi nedeniyle bireylerin izolasyonlarının sağlanabilmesi amacıyla video konferans araçları ile yürütülmüş her biri ortalama 25-30 dakika arası sürmüştür.

\section{Verilerin Analizi}

$\mathrm{Bu}$ çalışma kapsamında elde edilen verilerin analizinde betimsel analiz ve içerik analizi kullanılmıştır. Betimsel analizde veriler, önceden belirlenmiş temalara göre özetlenir ve yorumlanır (A. Yıldırım ve Şimşek, 2003). Betimsel analizde özetlenen ve yorumlanan veriler yüzeysel kalabileceği için bununla fark edilemeyen bazı kavramlar ve temalar ancak içerik analizi ile ortaya çıkarılabilir.

\section{Geçerlik ve Güvenirlik}

Araştırmada geçerlik- güvenirlik- güvenduyulabilirliğe ilişkin alınan bazı önlemler araştırmanın yöntem başlığı ve alt başlıkları altında detaylıca açıklanmıştır. Bunlar şu şekilde özetlenebilir:

- Araştırma boyunca alanyazın desteğine başvurulmuştur. 
- Görüşme formunun geliştirilmesi ve verilerin kodlanması başta olmak üzere tüm araştırma sürecinde nitelikleri yukarıda belirtilen uzmanların görüşleri sağlanmıştır.

- Çalışma grubu belirlenirken amaçlı örnekleme tekniği kullanılmıştır.

- Veri toplama sürecinde görüşme yapılan katılımcılardan anlık olarak katılımcı teyidi alınmıştır.

- Bulgular oluşturulurken elde edilen tema ve kodların güvenilirlik hesaplamasında Miles \& Huberman tarafından geliştirilen güvenirlik formülü (Güvenirlik = Görüş Birliği / (Görüş Birliği + Görüş Ayrılığı)) kullanılmıştır (Başkale, 2016). Hesaplama sonucunda araştırmanın güvenirliği 0,85 olarak hesaplanmıştır. $\mathrm{Bu}$ güvenirlik hesaplarının \%70'in üzerinde çıkması durumunda, araştırma sonuçlarının güvenilir olduğunu belirtilmektedir (Baltacı, 2017). Dolayısıyla, veri analizinde elde edilen sonucun araştırma için güvenilir olduğu söylenebilir.

\section{Etik Kurul Kararı}

Bu araştırma için Van Yüzüncü Yıl Üniversitesi Rektörlüğü Sosyal ve Beşeri Bilimleri Etik Kurulundan (25.02.2021-22116) etik izin alınmıştır.

\section{Bulgular}

\section{Birinci Alt Probleme İlişkin Bulgular}

Akademisyenlerle yapılan görüşmelerde "Akademisyenlerin Covid-19 öncesi UE deneyimleri nasıldır?" şeklinde belirlenen birinci alt probleme yanıt aramak amacıyla üç soru sorulmuştur:

Soru1: "Covid-19 pandemisi öncesinde UE veriyor muydunuz? Yanıtınız "evet" ise verdiğiniz eğitimin süresi ve kapsamı ile ilgili bilgi verebilir misiniz?”

Soru2: "UE ile ilgili herhangi bir eğitim aldınız mı? Yanıtınız "evet" ise aldığınız eğitim ile ilgili bilgi verebilir misiniz?”

Soru3: "Pandemi öncesinde eğitim süreçlerinde bilgi-iletişim teknolojilerinden faydalanıyor muydunuz? Yanıtınız "evet" ise ne tür teknolojilerden ve nasıl faydalaniyordunuz?"

Akademisyenlerin bu sorulara verdikleri yanıtların dağılımı Tablo 2, Tablo 3 ve Tablo 4'te sunulmuştur:

Tablo 2. “Covid-19 Pandemisi Öncesinde UE Veriyor Muydunuz?” Sorusuna Verilen Yanıtların Dăğlımı

\begin{tabular}{lcc}
\hline Alınan Yanıt & Frekans \\
\hline Hayır & & 5 \\
Evet & Bir proje kapsamında kısa süreli olarak & 2 \\
\hline
\end{tabular}




$\begin{array}{ll}\text { Birkaç kez, gönüllü özel ders biçiminde } & 1 \\ \text { Birkaç kez, şehir dışındayken derslerin aksamaması amacıyla } & 1 \\ 4 \text { haftalık bir uluslararası program kapsamında } & 1\end{array}$

Tablo 2' de görüldüğü gibi Soru1'e akademisyenlerin verdikleri yanıtlar genel olarak olumsuzdur. Beş akademisyen bu soruya doğrudan "Hayır” yanıtını verirken "Evet” yanıtı veren akademisyenlerden sadece birinin sistematik bir UE programı yürüttüğü bilgisine ulaşılmıştır. Dört akademisyen ise UE deneyimleri olduğunu ancak bunların ders kapsamında değerlendirilmemesi gerektiğini ifade etmişlerdir. Dolayısı ile katılımcıların hemen hepsinin UE deneyimlerinin olmadığı kanaatine varmak mümkündür. Sorul'e "Evet" yanıtı veren akademisyenlerin ifadeleri incelendiğinde verilen yanıtlar aşağıdaki şekildedir:

K1: “Evet verdim ancak sürekli ders anlamında değil, çeşitli etkinliklerle örneğin vitamin öğretmenin uzaktan eğitim uygulamaları vardı onlarl yaptık.”

K9: “Bir kere vermiştim. Vitamin’in organize ettiği bir ĕgitim vardl ylllar önce. Orada internet üzerinden online bir ders sunmuştum."

K3: "Evet, birkaç kez. Gönüllü olarak özel ders şeklinde uygulamalarım oldu. Tanımlı, planlı bir durum değildi.,"

K6: "Birkaç kez oldu. Mecbur kaldı̆̆ım durumlar olmuştu. Çeşitli etkinlikler için şehir dışında olduğumda dersleri uzaktan vermiştim."

K5: “Evet, verdim. Uluslararası bir eğitim programıydl. Uzaktan, video konferans yöntemiyle çevrimiçi olarak 4 haftalık bir ders programının bir parçası oldum."

Tablo 3. "UE ile İlgili Herhangi Bir Eğitim Aldınız mı?" Sorusuna Verilen Yanıtların Dağılımı

\begin{tabular}{lcc}
\hline Alınan Yanıt & Frekans \\
\hline Hayır & & 9 \\
Evet & $\begin{array}{l}\text { Pandemi ile birlikte, üniversite tarafından düzenlenen hizmet } \\
\text { içi eğitim kapsamında }\end{array}$ & 1 \\
& \\
\hline
\end{tabular}

Alt probleme cevap aramak amaciyla akademisyenlere sorulan ikinci soru olan "UE ile ilgili herhangi bir eğitim aldınız mı? Yanıtınız "evet” ise aldığınız eğitim ile ilgili bilgi verebilir misiniz?" sorusuna verilen yanıtlara bakıldığında Tablo 3 'te görüldüğü üzere dokuz akademisyen doğrudan "hayır" yanıtı vermiştir. Evet yanıtı veren akademisyen olan K7; "Evet aldım. Üniversite bu dönemde hizmet içi eğitim düzenlemişti. Kullandığımız UKEY (Uludağ Üniversitesi Kurum, Eğitim ve Araştırma Faaliyetleri Yönetişim Sistemi) sistemi bizlere uygulamalı bir biçimde gösterilmişti." şeklinde UE ile ilgili eğitim alma sürecinin 
pandemi ile birlikte başladığına işaret etmiştir. "Hayır" yanıtını veren bazı katılımcıların bu soruya verdikleri yanıtların devamında kullandıkları dikkat çekici ifadeler aşağıda aktarılmıştır:

K1: Üniversitede ben ĕgitim bilimleri mezunu olduğum için "eğitim teknolojileri" dersinde bununla ilgili içerikler vardı. Ayrıca özel bir eğitim almadım. Pandemi sürecinde de üniversite tarafindan bir ĕgitim verilmedi.

K2: Yok, almadım. Pandemi ile birlikte üniversite Youtube üzerinden videolar hazırladı sitemin nasıl kullanılacağına dair. Bu videoları izleyerek hazırlıklarımızı yaptık.

K3: Hayır. Üniversite bazı dokümanlar yayımlamıştı, onları inceledim sadece.

K8: Almadım. Üniversite basit bir çerçeve yönerge yayımladı. Onu inceleyip fikir sahibi oldum biraz.

Alınan bu yanıtlar, araştırmaya katılan akademisyenlerin hemen hepsinin UE'nin nasıl uygulanacağına dair herhangi bir eğitim almadığına işaret etmektedir.

"Pandemi öncesinde eğitim süreçlerinde bilgi-iletişim teknolojilerinden faydalanıyor muydunuz? Yanıtınız "evet" ise ne tür teknolojilerden ve nasıl faydalanıyordunuz?" biçimindeki Soru3'e akademisyenlerin verdikleri yanıtlardan elde edilen 'Kullandıkları Teknolojik Unsur" ve "Kullanım Biçimi” temalarına ilişkin kodlar ve frekansları Tablo 4'te yer almaktadir.

Tablo 4. Akademisyenlerin Pandemi Öncesi Teknoloji Kullanımları

\begin{tabular}{llc}
\hline Tema: & Kod: & Frekans \\
\hline Kullanılan Teknolojik Unsur & Bilgisayar & 10 \\
& Ofis (Sunu, kelime işlemci) yazılımları & 8 \\
& Projeksiyon cihazı & 4 \\
& Internet & 4 \\
& Etkileşimli tahta & 2 \\
& Video konferans yazılımları & 1 \\
& Nota düzenleme yazılımları & 1 \\
& Deney Simülasyonları & 1 \\
& e-kitap & 1 \\
\hline Öğretim etkinliklerinde & 10 \\
& Materyal desteği & 4 \\
& Sılnav hazırlama & 2 \\
& İletişim kurma & 2 \\
\hline
\end{tabular}


Tablo 4'te görüldüğü üzere Soru3'e verilen yanıtlarda en sık tekrar eden teknolojik unsur donanımsal olarak "bilgisayar", yazılım anlamında ise "Ofis yazılımları" olmuştur. Kullanım biçimi temasında ise en sık tekrar eden kod "öğretim etkinliklerinde” ifadesidir.

Alt probleme yanıt aramak amacıyla sorulan bu üç soruya alınan yanıtlar bütünsel olarak ele alındığında; akademisyenlerin bilişim teknolojilerine aşina olduğu, bu teknolojilerden pandemi öncesinde istifade ettikleri ancak bunun çoğunlukla bilgisayar ile sınırlı olduğu çıkarımı yapılabilir. Alınan yanıtlara bakıldığında görüşme yapılan akademisyenlerin geçmiş UE deneyimlerinin yetersiz olduğunu söylemek mümkün olabilir. Ayrıca bu akademisyenlerin neredeyse tamamı pandemi öncesi veya sonrası UE ile ilgili herhangi bir eğitim almamıştır. Tüm bunlar akademisyenlerin UE hazır bulunuşluklarında eksikler olduğu çıkarımını sağlayabilir.

\section{İkinci Alt Probleme İlişkin Bulgular}

“Akademisyenler AUE sürecinde hangi sorunlarla karşılaşmaktadırlar?” şeklinde belirtilen, araştırmanın dördüncü alt problemine dair veri toplamak amacıyla akademisyenlere AUE'de hangi sorunlarla karşılaştıkları sorusu yöneltilmiştir. $\mathrm{Bu}$ soruya alınan yanıtlar incelendiğinde Tablo 5'de yer alan sonuçlar ortaya çıkmıştır.

Tablo 5. Akademisyenlerin UE'de Karşılaştıkları Sorunlar

\begin{tabular}{|c|c|c|}
\hline Temalar: & Kodlar: & Frekans: \\
\hline $\begin{array}{l}\text { Teknolojik Altyapı } \\
\text { ve Yeterliğe Dair }\end{array}$ & $\begin{array}{l}\text { Akademisyen teknolojik hazır bulunuşluğundaki } \\
\text { yetersizlikler }\end{array}$ & 8 \\
\hline \multirow[t]{4}{*}{ Sorunlar } & Bağlantı sorunları (Yavaşlık, kopma vb.) & 7 \\
\hline & Teknolojiye erişememe (cihaz, internet) & 6 \\
\hline & Kullanılan ekipmanların yetersiz olması & 4 \\
\hline & Öğrencilerin teknolojik hazır bulunuşluğu zayıf & 3 \\
\hline İletişim & Sınırlı etkileşim & 9 \\
\hline Etkileşime Dair & Kapalı öğrenci kameraları & 6 \\
\hline \multirow[t]{2}{*}{ Sorunlar } & Samimiyetsizlik / Mekanik Ortam & 5 \\
\hline & Fiziksel temas eksikliği & 2 \\
\hline Öğretim Süreci ile & Motivasyon eksikliği & 12 \\
\hline \multirow[t]{4}{*}{ İlgili Sorunlar } & Öğrencinin dersi takibinin izlenememesi & 7 \\
\hline & Katılım düşüklüğü / düzensizliği & 6 \\
\hline & Sürece yönelik inanç & 5 \\
\hline & Ölçme değerlendirme ile ilgili sorunlar & 4 \\
\hline
\end{tabular}


Uygulamalı derslerdeki verimsizlik

Açık bırakılan mikrofonların ders akışını bozması

Daha fazla hazırlık gerektirmesi

\begin{tabular}{llc}
\hline İdari Sorunlar & Ders sürelerinin kısa olması & 2 \\
& Devam zorunluluğu olmaması & 2 \\
& Kalabalık sınıflar & 2 \\
\hline Diğer Sorunlar & Öğretim odaklı olması, eğitimin (ahlaki, insani & 1 \\
& değerler vb.) geri planda kalması & \\
& Öğrencilerin sosyal imkanlardan uzak kalması & 1
\end{tabular}

Tablo 5 incelendiğinde akademisyenlerin AUE'de karşılaştıkları sorunlar beş farklı tema altında ele alınmıştır. "Teknolojik Altyapı ve Yeterliğe Dair Sorunlar" temasında; "Akademisyen teknolojik hazır bulunuşluğundaki yetersizlikler", "bağlantı sorunları" ve "teknolojiye erişememe" kodları öne çıkmaktadır. "İletişim / Etkileşime Dair Sorunlar" temasında "sınırlı etkileşim”, "Öğretim Süreci ile İlgili Sorunlar" temasında ise "Motivasyon eksikliği" en sık tekrar eden kodlar olmuştur. Ayrıca "İdari Sorunlar" ve "Diğer Sorunlar" temalarında da bazı kodların oluştuğu görülmektedir. Yapılan görüşmelerde tüm bunlara ilişkin bazı katılımcı görüşleri şu şekildedir:

K1:” Ders süreleri oldukça kısa...Her öğrencide bilgisayar yok...Uygulama ăgırlık lı derslerde süreç zor...Açık bırakılan mikrofonlar dersin akışını bozuyor...Öğrencinin kamera açmaması da sorun. Öğrencilere sorduğumda "hocam sanayideyim, hocam arabadayım” gibi durumlar söz konusu. Belki de öğrenciler evlerinin görünmesinden rahatsı...Böyle samimiyetsiz bir durum var...̈̈ğrencilerin motivasyonu düşüyor. Çünkü fark edilmek istiyorlar ama olmuyor...Bu süreç sürpriz oldu. Herkes hazırlıksız yakalandı. Beklentiye uygun süreç olmayınca da etkisiz bir süreç oldu. Siz öğrenciyi yüz yüze eğitim vaadiyle okula aldınız. Ama bir anda bu şekilde olunca zihin uyum sağlayamadı. Hocalar da öyle. Uyum sağlayamadılar. Tersi durumda sürekli uzaktan eğitim veren bir hocayı da sınıfa sokarsanız aynı şey olurdu ... Yaşı ileri akademisyenler bu süreçte zorlandılar...Bu süreç etkili ve verimli değil. Duyu organlarının tamamını işin içine katmadığınız sürece eğitimde başarılı olmanız zor.”

K2: “En büyük sorun bizim veya öğrencilerin internet bağlantısındaki kopmalar. Bazı ögrenciler vize sınavında dahi bu sorunu yaşadılar... Derse katılımlar düzensiz...̈̈̆̆renci canlı derse katıllyor, katılımcı listesinde var ancak dersi takip edip etmediğini anlamak zor. 
Kameralar genellikle kapalı...Sınav güvenliği ile ilgili kaygılarımız var. Öğrenci isterse çok rahat kopya çekebilir, soruların yanıtlarını bulabilir."

K3: Öğrenci kamera açmıyor, mikrofon açmıyor. Böyle olunca iletişim döngüsü tamamlanmiyor. Ders mekanik bir hal allyor... Öğrencilerin ve hocaların teknolojiye yatkınlığı ve teknolojiye erişimi ciddi sıkıntılar. Orta yaş üzeri hocaların zorlandığını biliyorum...Bizim öğrenci profilimiz açısından tanımlı bir mekandan çıkarak esnek ders ortamı negatif bir etki oluşturdu... Her üniversite her hoca kendi bacağından asılıyor."

K5: "Değerlendirme süreçlerinde çok sıkıntı yaşadık. Öğrencilerin tüm kaynaklara erişebildiği esnek bir ortamda sınav olayı çok sağlıklı olmadı...Teknik sorunlar sıkça yaşıyoruz, internet kopması, bağlantı yavaşlı̆̆ gibi...Kullandığımız mikrofon, kamera vb ekipmanlar uzaktan eğitim için yeterli değil...Yüz yüze bir temas kuramıyoruz, vücut dili kullanımı söz konusu değil...Sınıf içi ortamdan uzaklaşmış olmamanın verdiği bir ciddiyetsizlik de söz konusu...̈̈ğrencinin dersi takip etme durumunu beden hareketlerini gözleyerek takip etme şansı olmuyor... Bir radyo programı yapıyor gibi, karşımızdakinin bizi dinlediğini varsayarak...Ne öğrenciler, ne akademisyenler bu duruma hazır değillerdi."

K7: “İletişim konusunda sorunlar oluyor. Çoğunlukla tek yönlü iletişime kaylyor dersler...Öğrenci kameraları kapalı olduğu için derse katılımı takip edemiyorsunuz...Devam zorunluluğu olmadĭ̆ için katılım oldukça düşüyor...Ekrana konuşuyormuş hissiyatı...Motivasyon yüz yüze eğitimle klyaslanamayacak ölçüde düşük...Bu döneme gençler dışında bizler hazır değildik. Başta oldukça zorlandık...Internet bă̆lantısında bazen donma kasma benzeri sorunlar meydana gelebiliyor ...Sinav güvenliği ile ilgili kaygllarım var.”

K8: "Derse katılımı takip edemiyoruz. Bazı öğrenciler sadece derste görünüyor. Söz hakkı veriyorum veya soru soruyorum zaman zaman ama ya karşılık alamıyorum ya da mikrofon bozuk, internet çekmiyor vs...Ben öğrencilerin derse katılmasına rağmen takip ettiklerine inanmıyorum...Uygulamaya dönük derslerde özellikle ölçme değerlendirmede sorun yaşıyoruz...Cihaz erişimi olmayan öğrenciler var ...Süreç verimli değil.,

K10: "En büyük sorun tüm ögrencileri, sınıfı bir arada görememek. Neredeyse yart yarıya katılım yok derslere...Sosyo-ekonomik eşitsizlikler ile tüm ögrencilerin eşit cihaz ve internet erişimine sahip olmaması...Öğrenciler derse odaklanamıyorlar...İstek, motivasyon oldukça düşük...Değgerlendirme süreçleri sorunlu...Bizim görevimiz sadece öğretim değil, eğitim de var. Uzaktan eğitimde ĕgitim eksik kalabiliyor. Insani veya ahlaki değerler kazandırma geri planda kalıyor...Sosyal yönden oldukça eksik kaldı öğrencilerimiz.”

\section{Üçüncü Alt Probleme İlişkin Bulgular}


Araştırmanın beşinci alt problemini oluşturan “AUE sürecinde karşılaşılan sorunlara karşı akademisyenler neler önermektedirler?” sorusuna dair veri toplamak amacıyla bir önceki alt problemde belirtilen "AUE'de karşılaşılan sorunlara ilişkin çözüm önerileriniz nelerdir?" ifadesi yöneltilmiştir. Akademisyenler bu soruya verdikleri yanıtlarla yapılan analiz sonucunda elde edilen kodlar Tablo 6'da sunulmaktadır.

Tablo 6. AUE'de Karşılaşılan Sorunlara Dair Akademisyenlerin Çözüm Önerileri Kod: Frekans:

Teknolojik araç desteği / Eşit kullanım olanaklarının sağlanması 5

Akademisyenlere hizmet içi eğitim verilmesi 4

Sinıf mevcutlarının azaltılması 3

Öğrencilere kamera açma zorunluluğu getirilmesi 3

Tüm üniversitelerin kullanacağı ortak bir sistem geliştirme / Merkezi organizasyon

Öğrencilere eğitim verilmesi 2

Akademisyenlere teknik destek verilmesi 2

Sınav güvenlik tedbirlerinin artırılması 2

Müfredat sadeleştirilmeli / yeniden yapılandırılmalı

Sürecin ciddiyetinin tüm paydaşlara aktarılması

Sanal sınıf, simülasyon, artırılmış gereklik uygulamaları yaygınlaştırılmalı

Ders sürelerinin artırılması

Derse katılım zorunlu olmalı

Görüldüğ̈̈ üzere akademisyenlerin UE’de karşılaşılan sorunlara getirdikleri çözüm önerilerinde en sık tekrar eden kodlar başlıca; "teknolojik araç desteği / eşit kullanım olanaklarının sağlanması”, “akademisyenlere hizmet içi eğitim verilmesi”, "sınıf mevcutlarının azaltılması” ve “öğrencilere kamera açma zorunluluğu getirilmesi” olmuştur. Akademisyenlerin bunlara ilişkin bazı ifadeleri şu şekildedir:

K1: "İmkânı kısıtlı olanlar için teknolojik araç desteği internet desteği ile katılım sağlanacaktır...Sınıf öğrenci sayıları az olursa etkileşim o denli artacaktır...”

K2: “Teknik bir konu kafama takıldı̆̆ında başvurabileceğim güçlü bir teknik destek ekibine ihtiyaç duyuyorum...Kamera açılmasının zorunlu olması gerekli. Özellikle sınav güvenliği için bu gerekli..."

K4: "Ders saatlerinin artırılması lazım ...Herkesin kamerasının açık olması lazım..." 
K5: “Öncelikle tüm ülkede ortak kullanılacak milli bir sistem geliştirilmeli. Geniş bir uzaktan eğitim ortak altyapısı kurulmalı...Bilgisayar, internet ile mikrofon, kamera gibi en temel ekipmanların herkes için aynı kalitede olacak şekilde temin edilmesi...Hem öğrencilere hem akademisyenlere kapsaml, zorunlu bir eğitim verilmesi..."

K6: "Uzaktan eğitimle ilgili bir ders olmalı lisans ĕgitiminde. Biz görmedik sıkıntısını şimdi yaşıyoruz. Şimdiki öğrencilerin de birer öğretmen adayı olarak gelecekte uzaktan eğitimi verimli kullanabilmeleri için böyle bir ders şart...Bende maksimum 15 kişilik olmalı siniflar."

K7: "Sınav güvenliği ile ilgili daha güvenilir yöntemler. Kamera, yüz tanıma, süre klsitlamast gibi..."

K8: “Öğretim üyelerine hem eğitim anlamında hem teknik olarak destek verilmeli...Derse katılım zorunlu olmall. Kamera ve mikrofonların açık tutulmasına dair hukuki düzenleme olabilir....Merkezi bir organizasyonla sanal sinfflarla birlikte stüdyolar kurularak profesyonel bir eğitim ortamı sunulabilir."

K9: “Öğretmenlik becerilerinin uygulamalı derslere dökülmesi için sanal sinıflarla simülasyon, sanal gerçeklik gibi uygulamalar olduğunu duymuştum. Bunlar yaygınlaştırılabilir...Sınıflar çok kalabalık bunun azaltılması gerekiyor."

K10: "Süreçlerin öğrencilerin daha sosyal yönlerine hitap edebilecek şekilde yeniden yapılandırılması gerekir. Böylelikle psikolojik olarak da gelişimleri daha iyi bir noktaya gelebilir. Mevcut müfredat uzaktan eğitime uygun olarak planlanmad, bu yüzden biraz sadeleşmeli."

\section{Dördüncü Alt Probleme İlişkin Bulgular}

Araştırmanın dördüncü ve son alt problemi olan “Akademisyenlerin UÖY’ye ilişkin görüşleri nelerdir?” problemine ilişkin veri toplamak amacıyla akademisyenlere “Öğretmenlik mesleğinin doğası, öğretmen yetiştirmenin önemi ve Covid-19 pandemi sürecinde eğitimin uzaktan veriliyor olması bağlamında UÖY'ye ilişkin görüşleriniz nelerdir?” sorusu yöneltilmiştir. Alınan yanıtların analizi yapıldığında oluşan kodlar Tablo 7'de yer almaktadır.

Tablo 7. Akademisyenlerin Uzaktan Öğretmen Yetiştirmeye Dair Görüşleri

\section{Tema:}

Olumsuz Görüş

Olumlu Görüş

Nötr Görüş

\section{Frekans:}


Akademisyenlerin UÖY’ye ilişkin görüşlerine bakıldığında olumsuz görüşlerin daha fazla olduğu görülmektedir. Bunun yanında olumlu ve nötr görüşler de mevcuttur. $\mathrm{Bu}$ görüşlere ilişkin bazı akademisyen ifadeleri şu şekildedir:

K1: "Üniversite hocalar ciddiye almadı bu süreci. "Gitsin, yaparak ögrensin" anlayışı var...Pandemi yakın zamanda sona ererse ders ve bilgi açısından bu açık kapatılabilir. Çünkü bilgi her yerde. Ancak bilgiye sahip olmak yetmiyor. Esasen ben ögretmenlik mesleğinin öğrenilen bir meslekten ziyade bir beceri mesleği olduğuna inanıyorum. Insanları seveceksiniz, yüksek düzeyde iletişim becerileriniz olacak, hoşgörülü olacaksınız, gülümseyeceksiniz, dokunacaksınız. Bunları nasıl öğretebiliriz? Bu nedenle bu süreç öğretmenlik alanlarını çok fazla etkilemedi bence. Çocukları sevmeyen bir öğretmen adayı için uzaktan eğitim veya yüz yüze olması neyi değişstirecek? Uzaktan ĕgitim veya yüz

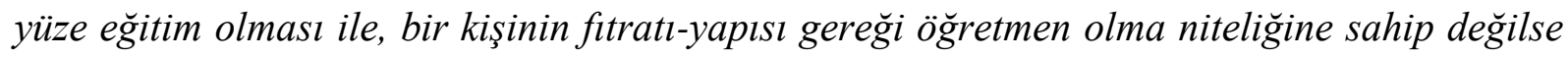
onda çok büyük değişiklik olmayacaktır...Ancak şöyle de bir tehlike var: özel sektör gelecekte bence pandemi döneminde üniversitede ögrenci olanları tercih etmeyecektir. Özel sektör bunu sorgular."

K2: “Daha önce de Açıköğretim 'den mezun olan öğrencileri biliyorum bize formasyon almaya gelen. Bu öğrencilerin çok zorlandı̆̆ını gördüm...Ben uzaktan eğitim ile öğretmen olunamayacă̆ını düşünüyorum.”

K3: "Çok büyük darbe vurduğunu düşünüyorum. Bunun acısını ilerde göreceğiz."

K4: "Öğretmen adayları staja gidemediler, uygulama derslerini göremediler. Bu nedenle eksik yetiştiler görüşündeyim. En iyi öğrenme yaparak yaşayarak öğrenme olduğundan staj büyük öneme sahip. Bu da olmayınca büyük eksiklik oldu."

K5: "Öğretmenlik mesleği uygulamalı bir alandır. Karşısındaki insan unsurudur. Uzaktan eğitimin ögretmen yetiştirmede çok büyük handikaplar doğurduğunu, doğuracă̆ını, öğretmen adaylarının çok büyük eksiklikler yaşayacağını düşünüyorum. Özellikle mesleklerinin ilk ylllarında bence çok zorlanacaklar."

K6: "Staja bile gidemeyen ögretmen adaylarl oldu. Bu da büyük eksiklik. Büyük sorunlar kapıda...Pandemi bize eksikleri gösterdi ayrıca. Devamlı güncellenmekte olan ĕgitim fakültesi programlarındaki eksikliği, ihtiyacı da gördük..."

K7: "Şu anki dönem çok şanssız bir dönem. Okula gelmeden üniversite yaşamının yarısı geçti öğrencilerin. Sadece eğitim-öğretim açısından değil üniversitelerin sosyal ve kültürel olanaklarından da uzak kaldı ögretmen adayları...Staj konusu oldukça önemli. Okul havasını soluyamadan mezun ettiğimiz ögretmen adayları oldu. Öğretmenlik deneyimi 
kazanamadan bitti okul. Bu da büyük eksiklik...Ancak teknoloji kullanımı, zorunlu durumlarda bir alternatif olması ve eğitimin sürdürülmesi anlamında katkıları da oldu bu sürecin. Bunun da ĕ̆itimin bir parçası olduğunu - olabileceğini gördük hepimiz. Öğretmen adayları da bunun içinde. Uzaktan eğitimi öğrenmek açısından bir firsat oldu aslında başka bir açıdan bakınca."

K8: "Öğretmen yetiştirme için uzaktan ĕgitim uygun değil. Neticede bu adaylar gidip çocuklarla iletişim kuracaklar. Ama bu dönem kendileri sağlıklı bir iletişim sürecinden geçerek eğitim almadılar. Üniversitede ne sağllklı bilgi alma firsatları oldu, ne sağlıklı uygulama yapabildiler ne de sağllklı bir değerlendirme - dönüt sisteminden geçtiler. Nasıl bir ögretmen olacaklarını biz de kendileri de bilmiyorlar bu yüzden. Her şey sanal bu süreçte...Uzaktan ĕgitim kalıcı olsa bile özellikle ĕgitim fakültelerinde uygulamalı dersler açısından tehlikeli olduğuna inanıyorum ...Şöyle bir klyaslama yapmak mümkün; biliyorsunuz Türk Dili ve Edebiyatı açıköğretim fakültesinde olan bir program. Buradan mezun olan bazı ögrenciler formasyon almaya geliyor. Doğrudan eğitim fakültesi okuyan öğrencilerle karşılaştırıldı̆̆ında, bu öğrenciler o kadar geride ki... Başarıda da böyle, hazır bulunuşlukta da öyle. Bu da açıköğretimde uzaktan eğitimin çok da başarılı olmadiğını zaten göstermişti. Geçmişte denendi bu. Işste mektupla eğitim vardl, işte 40 günde eğitim alıp öğretmen yapllan insanlar vardı...Sonucun hüsranla sonuçlandĭ̆ görüldü. Türk eğitimi için facia oldu bence bunlar...Faydalı olsaydı zaten tüm örgün eğitimler sona erdirilir, açıköğretimle öğretmen yetiştirirdik. Öğretmen olma niteliklerinin uzaktan ĕgitimle kazandırllması bence mümkün değgil."

K9: "Uzaktan ĕgitimin öğretmen eğitimi içinde olmasl gerektiğine inanıyorum. Belki bahar ve güz dönemi yerine 3 dönem şeklinde bir uygulamaya geçilip sadece uygulama gerektiren dersler için öğretmen adayları okula getirilip bu şekilde hem akademisyenlerin hem de öğretmen adaylarının zamanı daha etkin kullanabilmeleri să̆lanabilir. Ekonomik de olacaktır bu uygulama."

K10: "Biz bir şekilde ders verebiliyorsak uzaktan eğitimle, ögretmen adayları da teknolojik olarak bizlerden daha donanımlılar onlar hayli hayli hallederler bu süreci...Okul stajı yapamamak bir sıkıntı sadece ama diğer süreçler açısından bence çok etkilemedi bu durum. Hatta stajı bile uzaktan eğitime uygun almaları iyi bile oluyor bence. Mevcut ögretmenlerin bile ilk defa deneyimledikleri süreçlere ortak olarak eksik kalan yönlere, sorunlara bizzat tanık olarak bunlara yönelik tedbir alma noktasında bir avantaj olduğuna inanıyorum... Uzaktan da uygun yöntemlerle ögrretmen yetişebileceğini düşünüyorum. Kastım 
şu ögretmenliğe dayall meslek bilgisi dersleri veya diğer uygulamall dersler sadece bir slayttan okuma şeklinde yürütülüyorsa bunun tabi ki büyük bir problem yaratacă̆l da göz ardı edilmemeli."

\section{Sonuç, Tartışma ve Öneriler}

Eğitim fakültelerinde öğretmen yetiştirme alanında görevli akademisyenlerin geçmiş UE deneyimleri, AUE'de karşılaştıkları sorunlar ve bunlara çözüm önerileri ile UÖY'ye dair görüşlerinin incelendiği bu çalışmadan elde edilen bazı sonuçlar şöyledir: Araştırmaya katılan akademisyenlerin pandemi öncesi UE deneyimleri oldukça sınırlı olup sistematik bir UE programı uygulayan akademisyen neredeyse yoktur. Ayrıca bu akademisyenlerin AUE ile ilgili herhangi bir eğitim almadıkları görülmektedir. Bu sonuçlarla beraber; akademisyenlerin UE, AUE ve UÖY'ye ilişkin görüşlerine dair sonuçlar ortaya çıkarılmış, bu sonuçlar alt problemlerin sırasına uygun biçimde aşağıda tartışılarak çeşitli önerilerde bulunulmuştur.

Çalışma sonunda katılımcıların pandemi öncesinde genellikle UE yoluyla ders vermedikleri ve yine bu katılımcıların tamamına yakınının UE ile ilgili herhangi bir eğitim almadıkları ortaya çıkmıştır. Katılımcıların pandemi öncesi öğretim süreçlerinde yararlandıkları teknolojik unsurlarda tamamının bilgisayar kullandığı ancak bu kullanımın genellikle öğretim süreçlerinde sunum yapmak amacıyla ofis programları ile sınırlı olduğu görülmüştür. ÖYS, e-posta, bulut depolama, video konferans uygulamaları gibi yanıtların bulunmaması ise dikkat çekicidir. Bu durum teknolojik okur-yazarlık düzeyinin düşük olması ile ilişkilendirilebilir. Tüm bunlar birlikte ele alındığında eğitim fakültelerinde ders veren akademisyenlerin UE deneyimlerinin oldukça sınırlı olduğu ve AUE'ye karşı hazır bulunuşluklarının yeterli düzeyde olmadığı şeklinde yorumlanabilir. Pandemi döneminde Türkiye' deki yükseköğretim kurumlarının AUE uygulamalarının incelendiği bir çalışmada da, öğreticilerin çok azının UE’ye yönelik bir eğitim aldığı ve bunun çeşitli sorunlara yol açabileceği raporlanmıştır (Yavuz vd., 2020). De Jong (2020), pandemi sürecinde öğretmenlerin AUE deneyimlerini incelediği bir çalışmada birçok eğitimcinin covid-19 pandemisine kadar, UE'yi hiç deneyimlememiş oldukları sonucuna ulaşmıştır. Araştırmacı bu durumu öğretmen eğitiminin bu yöndeki eksiklikleri ile ilişkilendirmekte ve müfredat yapısında değişiklik yapılması gerektiğini savunmaktadır. Akademisyenler ise hizmet sürecinde bulunduğundan bu eksiklikler ancak hizmet içi eğitimler ile giderilebilir. $\mathrm{Bu}$ bağlamda özellikle pandemi ile başlayan AUE sürecinde YÖK ve üniversiteler tarafindan akademisyenlere yönelik teknolojik okur-yazarlık ve UE’ye dair hazır bulunuşluğu artırabilecek faaliyetler planlanması önerilebilir. 
Çalışmadan elde edilen bir başka sonuç akademisyenlerin AUE sürecinde birçok sorunla karşılaştığıdır. Bu sorunlar beş grupta incelenmektedir: "Teknolojik Altyapı ve Yeterliğe Dair Sorunlar”, “İletişim / Etkileşime Dair Sorunlar”, “Öğretim Süreci ile İlgili Sorunlar", "İdari Sorunlar" "ve "Diğer Sorunlar". Teknolojik Altyapı ve Yeterliğe Dair akademisyenlerin gündeme getirdikleri sorunların başında "akademisyen teknolojik hazır bulunuşluklarındaki yetersizlikler” gelmektedir. Katılımcıların sıklıkla bu sorundan söz etmeleri, çalışmanın ilk alt probleminde ortaya konan sonuçları destekler niteliktedir. Akademisyenlerin bizzat kendileri bu sürece hazır olmadıklarını belirtmektedirler. Covid-19 pandemisi sürecinde Türkiye'deki AUE uygulamalarının ele alındığı farklı bir çalışmada da akademisyenlerin BT kullanımı, sunum hazırlama, sunum yapma, interneti eğitim amaçlı olarak kullanma gibi konularda hazır bulunuşluk yetersizlikleri raporlanmıştır (Can, 2020). $\mathrm{Bu}$ yetersizliklerin öğretim süreçlerine olası olumsuz etkilerini en aza indirmek adına durum tespiti yapılarak akademisyenlere gerekli teknik - eğitsel destek sağlanmalıdır.

Akademisyenler genel olarak kendilerinin veya öğrencilerin internet bağlantısında donma, kopma, yavaşlık gibi bağlantı sorunları yaşadıklarını sıkça belirtmişlerdir. Pandemi sürecindeki AUE uygulamalarını farklı paydaşlar yönünden inceleyen birçok çalışmada elde edilen sonuçlar da benzer şekildedir (Can, 2020; Fidan, 2020; Kurnaz ve Serçemeli, 2020). Bu durumların iletişim kaynaklı ve öğretim süreçlerine yönelik birçok soruna da kaynaklık edebileceğini söylemek mümkündür. $\mathrm{Bu}$ bağlamda ilgili kurum/kuruluşlarla iş birliği yapılarak internet altyapısında iyileştirmeler sağlanması bu tür sorunların önüne geçilmesine yardımcı olabilir.

Teknolojik Altyapı ve Yeterliğe Dair sıkça ifade edilen bir başka sorun da çok sayıda öğrencinin teknolojiye erişimle ilgili -muhtemelen sosyoekonomik nedenlerle- sorun yaşıyor olmasıdır. Pandemi döneminde Türkiye'deki yükseköğretim kurumlarının AUE uygulamalarının incelendiği bir çalışmada da bu sorun ele alınmıştır (Yavuz vd., 2020). Teknolojiye erişim sorunu, derse katılımları doğrudan etkilemektedir. Derse katılamayan öğrencinin de o dersteki başarısı tartışılabilir bir husustur (Hofer vd., 2021; Hsin ve Cigas, 2013; Khlaif vd., 2021). Bu bağlamda derse katılımlarını sağlayabilmek adına tüm öğrencilere internet bağlantısı bulunan bir cihaz temin edilebilir. Bunun için üniversiteler; ilgili bakanlıklar ve sivil toplum kuruluşları ile iş birliği yapabilir.

İletişim / Etkileşime Dair Sorunlar altında katılımcılar tarafından en sık tekrar edilen ifade "sınırlı etkileşim" olmuştur. Akademisyenler ortamın mekanik olmasının ve diğer bazı sorunlardan kaynaklanan etkileşim zayıflığının öğretim süreçlerine zarar verdiğini 
belirtmektedirler. Buna gerekçe olarak da en fazla ifade edilen durumların başında öğrencilerin ders esnasında kameralarını kapalı tutmaları gelmektedir. Öğretim süreçlerinin etkili ve verimli bir şekilde başarıya ulaşmasında iletişimin önemi düşünüldüğünde (BenYishay ve Mobarak, 2014; Deryakulu, 1991), bu durumun öğretim süreçlerine etki eden bazı sorunlara da gebe olduğu öngörülebilir. Yükseköğretim programlarında web tabanlı UE'de yaşanan sorunların incelendiği bir çalışmada da UE'de yüz yüze etkileşim eksikliğinin yaşandığı belirtilmiş ve bu eksikliğin giderilmesinde güncel teknolojilerin doğru stratejilerle kullanılması ve hem öğretim elemanı hem de UE birimi tarafinda iletişim ve destek sistemlerinin etkin kullanılması gerektiği önerilmiştir (Bilgiç ve Tüzün, 2015). Bu çalışmada akademisyenlerin yaşadığı sorunlarda diğer bir tema olan "Öğretim Süreci ile İlgili Sorunlar" içerisinde de en sık tekrar edilen hususlardan biri de iletişim kaynaklı olduğu değerlendirilen "öğrencinin dersi takibinin izlenememesi” olmuştur. Bunun da; sınıf yönetiminin zorluğundan, akademisyen motivasyonun düşüklüğüne kadar birçok olumsuzluğa kaynaklık edebileceği düşünülebilir. Belirtilen bu sorunları en aza indirmek için öğrenci kameralarının açılmasını zorunlu hale getirici bazı önlemler, karar vericiler tarafından alınabilir. Bu sayede öğrencilerin dersi takibinin izlenememesi sorununun da önüne geçilebilir. Ayrıca öğretim süreçlerindeki tüm paydaşların birbirini görüyor olması, bu süreçleri etkili ve verimli hale getiren iletişim ve etkileşim önündeki engelleri azaltabilir.

Akademisyenlerin karşılaştıkları Öğretim Süreci ile İlgili Sorunlar incelendiğinde; motivasyon eksikliği, katılım düşüklüğü, sürece yönelik inanç ve ölçme değerlendirme ile ilgili sorunlar bulunduğu görülmektedir. Motivasyon ve başarı arasında doğrudan bir ilişki olduğu birçok araştırmada ortaya koyulmuştur (Anderman ve Dawson, 2011; BenYishay ve Mobarak, 2014; Pintrich, 2003). Öğretim süreçlerinin belirlenen amaçlara ulaşmasında hem öğreticiler hem de öğrenciler açısından motivasyon unsurunun önemli payı bulunmaktadır (Harandi, 2015). Karşılaşılan sorunların belki de en fazla üzerinde durulması gerekeni motivasyon eksikliğidir. Katılımcılar hem kendilerinin hem de öğrencilerinin bu sorunu yaşadıklarından sıkça söz etmektedirler. Pandemi sürecindeki AUE uygulamalarına yükseköğrenim öğrencilerinin tutumlarını ele alan bir çalışmada da motivasyonun düşmesi önemli bir sorun olarak belirtilmiştir (Altuntaş Yılmaz, 2020). Alanyazında motivasyonu düşürebilecek bazı faktörler belirsizlik hissi, kaygı, iletişim eksikliği, uyum sağlayamama şeklinde belirlenmiştir (Anderman ve Dawson, 2011; Dörnyei, 1998; Harandi, 2015). AUE faaliyetlerinin beklenmedik ve ani bir biçimde uygulamaya geçmesinin, bu faktörleri tetiklemesi muhtemeldir. Buna yönelik alınabilecek tedbirlerden biri; hem akademisyenleri 
hem de öğrencileri sürece zihinsel olarak hazırlayabilecek, alanında uzman psikolog, sosyolog, kişisel gelişim uzmanı vb. kişileri işe koşarak seminer benzeri etkinliklerin düzenlenmesi olabilir.

Öğretim Süreci ile İlgili Sorunlar altında sıkça ifade edilen bir başka durum derslere katılım oranının düşüklüğü / düzensiz katılımlar olmuştur. Yukarıda da ifade edildiği üzere, derslere katılmayan öğrencilerin başarı durumları tartışmalı bir konudur. Bazı araştırmacılar, öğretim süreçlerinin etkili ve verimli olmasının, öğrencilerin etkin katılımına bağlı olduğunu iddia etmektedir (Durdu ve Albayrak, 2015; Yuksel, 2009). Bu bağlamda; yaşanan katılım sorunlarının önüne geçebilmek, eşit erişim imkanlarının sağlanması koşuluyla, karar vericiler tarafından derslere devam zorunluluğunun getirilmesi ile mümkün olabilir.

Akademisyenlerin öğretim süreçleri ile ilgili karşılaştıkları bir diğer sorun ölçmedeğerlendirme süreçleri ile ilgilidir. Birçok akademisyen AUE süreçlerinde uygulanan ölçmedeğerlendirme faaliyetlerinin güvenilir olmadığından yakınmaktadırlar. Çevrimiçi gerçekleştirilen sınavlardaki kopya riskinin yüksek olması, akademisyenleri kaygılandırmaktadır. Hodges vd. (2020), AUE süreçlerinde geleneksel ölçme-değerlendirme tekniklerinin aksine AUE’ye uygun ölçme-değerlendirme tekniklerinin kullanılması gerekliliği belirtmektedirler. Bu bağlamda ölçme-değerlendirme süreçlerinin daha sağlıklı yürütülebilmesi adına üniversitelerde UE Ölçme-Değerlendirme Birimi gibi oluşumlar kurulabilir. Çevrimiçi sınavlarda güvenliğin artırılması amacıyla süreli sınav sistemleri, yüz tanıma, uyarlanabilir sınav alt yapısının kurulması vb. uygulamalar kullanılabilir.

Araştırmanın üçüncü alt problemi doğrultusunda akademisyenlerden AUE sürecinde karşılaşılan sorunlara çözüm önerileri getirmeleri istenmiştir. Toplam kod sayısına bakıldığında katılımcıların bu konuda çok fazla üretken olduğunu ifade etmek güçtür. Getirilen öneriler incelendiğinde en fazla tekrarlayan ifadelerin "Teknolojik araç desteği / Eşit kullanım olanaklarının sağlanması", "Akademisyenlere hizmet içi eğitim verilmesi”, "Sınıf mevcutlarının azaltılması" ve "öğrencilere kamera açma zorunluluğu getirilmesi” olduğu görülmektedir. Verilen yanıtlar bütünsel olarak ele alındığında çözüm önerilerinin genellikle derslere katılımı artırmayı, iletişim/etkileşimi güçlendirmeyi ve teknolojik hazır bulunuşlukları ilerletmeyi amaçladığı ifade edilebilir.

Araştırmanın son alt problemi olan Akademisyenlerin UÖY'ye yetiştirmeye ilişkin görüşleri ele alındığında, olumlu, olumsuz ve nötr yönde bazı görüşler ortaya çıkmıştır. Bu görüşlerin genellikle olumsuz yönde olduğu görülmektedir. Nötr görüşler genellikle AUE’nin öğretmen yetiştirme sürecine herhangi bir etkisi olmadığı şeklinde belirtilirken, olumlu bazı 
görüşler; "bu süreç öğretmen adaylarının uzaktan eğitimi öğrenmesi açısından bir firsat oldu" ve "uzaktan eğitim öğretmen eğitiminde olmalı" şeklinde ifade edilmiştir. Öğretmen adayları ile yapılan benzeri bir çalışmada da aday öğretmenler, AUE’nin bu süreçte test edilmesi ve aksaklıklarının belirlenmesini olumlu olarak nitelemişlerdir (Görgülü Arı ve Hayır Kanat, 2020). Dolayısıyla bu kriz durumunun firsata çevrilebilmesi için günümüzde öğretmen eğitiminde bir dönüşüme gidilmesi tartışılabilir (Sezgin, 2021). Bu bağlamda özellikle öğretmen yetiştiren programlarda UE'ye yönelik uygulamalar içeren seçmeli dersler verilebilir.

UÖY'ye yönelik tüm bu görüşlere karşın olumsuz yönde birçok görüş mevcuttur. Akademisyenler bu görüşleri; "Staj / uygulamalı dersler eksik kaldı, bu bir sorun”, "Sürecin öğretmen yetiştirmeye zarar verdiğini düşünüyorum”, "Uzaktan eğitim ile öğretmen olunamayacağını düşünüyorum” gibi ifadelerle belirtmişlerdir. Öğretmenliğin uygulamalı bir alan olması, süreçte karşılaşan sorunlar ve AUE'nin sınırlıkları tümüyle ele alındığında AUE sürecinin öğretmen eğitimine zarar verdiğini söylemek mümkündür. Alınabilecek önlemler ile bu zarar belli ölçüde azaltılabilir. Farklı bir araştırmanın öğretmen adayları örneklemi üzerinde yürütülmesi ile sürecin bir diğer paydaşı olan öğretmen adaylarının AUE ve UÖY sürecine ilişkin görüşlerinin incelenmesi önerilebilir.

\section{Makalenin Bilimdeki Konumu}

Bilgisayar ve Öğretim Teknolojileri Eğitimi

\section{Kaynaklar}

Altuntaş Yılmaz, N. (2020). Yükseköğretim kurumlarında Covid-19 pandemisi sürecinde uygulanan uzaktan eğitim durumu hakkında öğrencilerin tutumlarının araştırılması: Fizyoterapi ve rehabilitasyon bölümü örneği. Necmettin Erbakan Üniversitesi Sağlık Bilimleri Fakültesi Dergisi, 3(1), 15-20.

Anderman, E. M. ve Dawson, H. (2011). Handbook of research on learning and instruction. Routledge.

Bakioğlu, B., ve Çevik, M. (2020). Covıd-19 pandemisi sürecinde fen bilimleri öğretmenlerinin uzaktan eğitime ilişkin görüşleri. Turkish Studies, 15 (4), 109-129.

Baltac1, A. (2017). Nitel veri analizinde Miles-Huberman modeli. Ahi Evran Üniversitesi Sosyal Bilimler Enstitüsü Dergisi, 3 (1), 1-14. 
Başaran, M., Doğan, E., Karaoğlu, E. ve Şahin, E. (2020). Koronavirüs (Covid-19) pandemi sürecinin getirisi olan uzaktan eğitimin etkililiği üzerine bir çalışma. Academia Ĕgitim Araştırmaları Dergisi, 5 (2), 179-209.

Başkale, H. (2016). Nitel araştırmalarda geçerlik, güvenirlik ve örneklem büyüklüğünün belirlenmesi. Dokuz Eylül Üniversitesi Hemşirelik Fakültesi Elektronik Dergisi, 9 (1), 23-28.

Bates, A. W. ve Bates, T. (2005). Technology, e-learning and distance education. Psychology Press.

BenYishay, A., ve Mobarak, A. M. (2014). Social learning and communication. National Bureau of Economic Research. 20139.

Bilgiç, H. G. ve Tüzün, H. (2015). Yükseköğretim kurumları web tabanlı uzaktan eğitim programlarında yaşanan sorunlar. Açıköğretim Uygulamaları ve Araştırmaları Dergisi, 1 (3), 26-50.

Bozkurt, A. (2020). Koronavirüs (Covid-19) pandemi süreci ve pandemi sonrası dünyada eğitime yönelik değerlendirmeler: Yeni normal ve yeni eğitim paradigması. Açıköğretim Uygulamaları ve Araştırmaları Dergisi, 6 (3), 112-142.

Bozkurt, A. ve Sharma, R. C. (2020). Emergency remote teaching in a time of global crisis due to CoronaVirus pandemic. Asian Journal of Distance Education, 15 (1), i-vi.

Can, E. (2020). Coronavirüs (Covid-19) pandemisi ve pedagojik yansımaları: Türkiye'de açık ve uzaktan eğitim uygulamaları. Açıköğretim Uygulamaları ve Araştırmaları Dergisi, $6(2), 11-53$.

Clark, J. T. (2020). Distance education. (ed. Ernesto Iadanza). Clinical Engineering Handbook. Academic Press.

Çă̆ıltay, K., Yıldırım, S., Arslan, I., Gök, A., Gürel, G., Karakuş, T., ... ve Yıldız, I. (2007). Öğretim teknolojilerinin üniversitede kullanımına yönelik alışkanlıklar ve beklentiler: Betimleyici bir çalışma. Akademik Bilisim’07-IX. Akademik Bilişim Konferansı Bildirileri, 31.

Çakın, M. ve Külekçi Akyavuz, E. (2020). Covid-19 süreci ve eğitime yansıması: öğretmen görüşlerinin incelenmesi. International Journal of Social Sciences and Education Research, 6 (2), 165-186. 
De Jong, P. G. (2020). Impact of moving to online learning on the way educators teach, [https://link.springer.com/article/10.1007/s40670-020-01027-7], Erişim tarihi: 10.02.2021.

Demir, Ö. (2015). Öğrencilerin ve ögrretim elemanlarının e öğrenmeye hazır bulunuşluk düzeylerinin incelenmesi: Hacettepe Üniversitesi Eğitim Fakültesi örneği. Hacettepe Üniversitesi: Yayımlanmamış yüksek lisans tezi.

Deryakulu, D. (1991). Eğitim teknolojisi, iletişim, öğrenme. Ankara Üniversitesi Ĕ̆itim Bilimleri Fakültesi Dergisi, 24 (2), 527-531.

Dörnyei, Z. (1998). Motivation in second and foreign language learning. Language Teaching, 31 (3), 117-135.

Durak, G., Çankaya, S. ve İzmirli, S. (2020). Covıd-19 pandemi döneminde Türkiye’deki üniversitelerin uzaktan eğitim sistemlerinin incelenmesi. Necatibey Eğitim Fakültesi Elektronik Fen ve Matematik Ĕ̈itimi Dergisi, 14(1), 787-809.

Durdu, E. ve Albayrak, M. (2015). Öğrencilerin uzaktan öğrenmeye ilişkin alg1 ve tutumlarının değerlendirilmesi. International Journal of Social Sciences and Education Research, 6 (2), 252-268.

Ekinci, T. A. (2015). Türkiye’de uzaktan öğretim yapan yükseköğretim kurumlarının örgütsel ve yönetsel açıdan karşılaştırılması. Muğla Sitkı Koçman Üniversitesi: Yayımlanmamış yüksek lisans tezi.

Fidan, M. (2020). Covid-19 belirsizliğinde eğitim: İlkokulda zorunlu uzaktan eğitime ilişkin öğretmen görüşleri. Uşak Üniversitesi Eğitim Araştırmaları Dergisi, 6 (2), 24-43.

Glesne, C. (2013). Nitel araştırmaya giriş (2. Baskı). (çev. Ali Ersoy-Pelin YALÇINOĞLU). Ankara: Anı Yayınc1lı.

Görgülü Arı, A. ve Hayır Kanat, M. (2020). Covid-19 (Koronavirüs) üzerine öğretmen adaylarının görüşleri. Yüzüncü Yıl Üniversitesi Sosyal Bilimler Enstitüsü Dergisi, Salgin Hastalıklar Özel Sayısı, 459-492

Gürer, M. D., Tekinarslan, E. ve Yavuzalp, N. (2016). Çevrimiçi ders veren öğretim elemanlarının uzaktan eğitim hakkındaki görüşleri. Turkish Online Journal of Qualitative Inquiry, 7 (1). 
Harandi, S. R. (2015). Effects of e-learning on Students' Motivation. Procedia-Social and Behavioral Sciences, 181, 423-430.

Hodges, C., Moore, S., Lockee, B., Trust, T. ve Bond, A. (2020). The difference between emergency remote teaching and online learning. Educause Review, 27 (1), 1-9.

Hofer, S. I., Nistor, N. ve Scheibenzuber, C. (2021). Online teaching and learning in higher education: Lessons learned in crisis situations. Computers in Human Behavior, 121, 106789.

Horzum, M. B., Özkaya, M., Demirci, M. ve Alpaslan, M. (2013). Türkçe uzaktan eğitim araştırmalarının incelenmesi. İn̈nü Üniversitesi Ĕgitim Fakültesi Dergisi, 14 (2), 79 100 .

Hsin, W. J. ve Cigas, J. (2013). Short videos improve student learning in online education. Journal of Computing Sciences in Colleges, 2 8(5), 253-259.

İşman, A. (2011). Uzaktan Eğitim. (4.Bask1). Ankara: Pegem Akademi.

Kahraman, M. E. (2020). Covıd-19 salgınının uygulamalı derslere etkisi ve bu derslerin uzaktan eğitimle yürütülmesi: Temel tasarım dersi örneği. Medeniyet Sanat Dergisi, 6 (1), 44-56.

Karakuş, N., Ucuzsatar, N., Karacaoğlu, M. Ö., Esendemir, N. ve Bayraktar, D. (2020). Türkçe öğretmeni adaylarının uzaktan eğitime yönelik görüşleri. RumeliDE Dil ve Edebiyat Araştırmaları Dergisi, (19), 220-241.

Kaya, Z. (2002). Uzaktan ĕgitim. (1. Bask1). Ankara: Pegem Akademi.

Kaysi, F. (2020). Covid-19 Salgını Sürecinde Türkiye'de Gerçekleştirilen Uzaktan Eğitimin Değerlendirilmesi. 5th International Scientific Research Congress (IBAD - 2020), 1-2 Eylül 2020.

Keegan, D. (1996). Foundations of distance education. RoutledgeFalmer.

Keskin, M. ve Özer Kaya, D. (2020). Covıd-19 sürecinde öğrencilerin web tabanlı uzaktan eğitime yönelik geri bildirimlerinin değerlendirilmesi. İzmir Kâtip Çelebi Üniversitesi Sağllk Bilimleri Fakültesi Dergisi, 5 (2), 59-67.

Khlaif, Z. N., Salha, S. ve Kouraichi, B. (2021). Emergency remote learning during COVID19 crisis: Students’ engagement. Education and Information Technologies, 1-23. 
Kırık, A. M. (2014). Uzaktan eğitimin tarihsel gelişimi ve Türkiye'deki durumu. Marmara İletişim Dergisi, (21), 73-73.

Kırmızıgül, H. G. (2020). Covid-19 salgını ve beraberinde getirdiği eğitim süreci. Avrasya Sosyal ve Ekonomi Araştırmaları Dergisi, 7 (5), 283-289.

Kurnaz, E. ve Serçemeli, M. (2020). Covid-19 pandemi döneminde akademisyenlerin uzaktan eğitim ve uzaktan muhasebe eğitimine yönelik bakış açıları üzerine bir araştırma. Uluslararası Sosyal Bilimler Akademi Dergisi, (3), 262-288.

Kürtüncü, M. ve Kurt, A. (2020). Covid-19 pandemisi döneminde hemşirelik öğrencilerinin uzaktan eğitim konusunda yaşadıkları sorunlar. Avrasya Sosyal ve Ekonomi Araştırmaları Dergisi, 7 (5), 66-77.

Mhlanga, D. ve Moloi, T. (2020). COVID-19 and the digital transformation of education: What are we learning on 4IR in South Africa. Education Sciences, 10 (7), 180.

Milli Eğitim Bakanlığı (MEB). (2020). Bakan Selçuk, Koronavirüs'e karşı eğitim alanında alınan tedbirleri açıkladı, [http://www.meb.gov.tr/bakan-selcuk-koronaviruse-karsiegitim-alaninda-alinan-tedbirleri-acikladi/haber/20497/tr], Erişim tarihi: 12.12.2020.

Naidu, S. (2006). E-learning: A guidebook of principles, procedures and practices. Commonwealth Educational Media Centre for Asia (CEMCA).

Orakçığlu, E. (2019). Türkiye'de uzaktan eğitim temalı 2013-2018 yılları arasında yapılan lisansüstü tezlerin incelenmesi. Eskişehir Osmangazi Üniversitesi: Yayımlanmamış yüksek lisans tezi.

Pektekin, P. (2013). Web tabanlı uzaktan eğitimde teknoloji kabulünün eğitim becerisi üzerindeki rolü: Türk üniversitelerinde akademisyenler üzerine bir araştırma. Marmara Üniversitesi: Yayımlanmamış doktora tezi.

Pintrich, P. R. (2003). Motivation and classroom learning. In (ed. W. M. Reynolds ve G. E. Miller). Handbook of psychology: Educational psychology, John Wiley \& Sons Inc.

Roberts, L. (2015). Exploring education and childhood. Routledge.

Sadi, S., Şekerci, A., Kurban, B., Topu, F., Demirel, T., Tosun, C., Demirci, T., Göktaş, Y. (2010). Öğretmen eğitiminde teknolojinin etkin kullanımı: Öğretim elemanları ve öğretmen adaylarının görüşleri. Bilişim Teknolojileri Dergisi, 1 (3), 43-49. 
Sayan, H. (2020). Covid-19 pandemisi sürecinde öğretim elemanlarının uzaktan eğitime ilişkin görüşlerinin değerlendirilmesi. AJIT-e: Bilişsim Teknolojileri Online Dergisi, 11 (42), 100-122.

Sezgin, S. (2021). Acil uzaktan eğitim sürecinin analizi: Öne çıkan kavramlar, sorunlar ve çıkarılan dersler. Anadolu Üniversitesi Sosyal Bilimler Dergisi, 21 (1), 273-296.

Shim, T. E. ve Lee, S. Y. (2020). College students’ experience of emergency remote teaching due to COVID-19. Children and Youth Services Review, 119, 105578.

Türkiye Cumhuriyeti (T.C.) Sağlık Bakanlığı. (2020). Türkiye'deki Koronavirüs Güncel Durumu, [https://covid19.saglik.gov.tr], Erişim tarihi: 12.12.2020.

UNESCO. (2020). Distance learning solutions, [https://en.unesco.org/covid19/educationresponse/solutions], Erişim tarihi: 12.12.2020.

Urdan, T. ve Weggen, C. (2000). Corporate E-learning: Exploring a new frontier. WR Hambrecht+Co.

Wikipedia. (2020). Impact of the 2019-20 coronavirus pandemic on education, [https://en.wikipedia.org/wiki/Impact_of_the_2019\%E2\%80\%9320_coronavirus_pand emic_on_education], Erişim tarihi: 12.12.2020.

World Health Organization (WHO). (2020). WHO Director-General's opening remarks at the media briefing on COVID-19, [https://www.who.int/dg/speeches/detail/who-directorgeneral-s-opening-remarks-at-the-media-briefing-on-covid-19---11-march-2020], Erişim tarihi: 12.12 .2020 .

Yavuz, M., Kayalı, B., Balat, Ş. ve Karaman, S. (2020). Salgın sürecinde Türkiye'deki yükseköğretim kurumlarının acil uzaktan öğretim uygulamalarının incelenmesi. Milli Ĕ̈itim Dergisi, 49 (1), 129-154.

Yıldırım, A. ve Şimşek, H. (2003). Sosyal bilimlerde nitel araştırma yöntemleri. Seçkin Yayıncilik.

Yuksel, I. (2009). Instructor competencies for online courses. Procedia - Social and Behavioral Sciences, 1 (1), 1726-1729. 
Yükseköğretim Kurulu (YÖK). (2020). Basın Açıklaması,

[https://www.yok.gov.tr/Sayfalar/Haberler/2020/universitelerde-uygulanacak-uzaktanegitime-iliskin-aciklama.aspx], Erişim tarihi: 12.12.2020.

Zan, N. ve Zan, B. U. (2020). Koronavirüs ile acil durumda eğitim: Türkiye'nin farklı bölgelerinden uzaktan eğitim sistemine dahil olan edebiyat fakültesi öğrencilerine genel bakış. Journal of Turkish Studies, 15 (4), 1367-1394.

\section{Summary}

\section{Statement of Problem}

Coronavirus (Covid-19), which was first detected in China-Wuhan in December 2019, infected a large number of people in a short time, making them sick and causing many deaths. It was announced as a global pandemic by the World Health Organization (WHO) and caused significant effects in all areas of life, especially in the field of health (WHO, 2020). The Covid-19 pandemic has also affected education systems around the world, causing all educational institutions to stop face-to-face education widely (Wikipedia, 2020). In the face of the inability to carry out education and training activities, which is one of the most fundamental rights of people, DE applications have come to the fore as a basic solution on a global scale (UNESCO, 2020). All these developments paved the way for the emergence of a new concept called Emergency Distance Education (EDE) (Hodges, Moore, Lockee, Trust, \& Bond, 2020).

Although EDE activities continued during the pandemic process are seen as similar to traditional DE activities, there are some differences between the two (Bozkurt and Sharma, 2020; Hodges et al., 2020). One of the prominent differences is related to the planning dimension. While traditional DE activities have a long and detailed planning process, AUE planning and decisions made during the pandemic period are fast (Yavuz, Kayalı, Balat, \& Karaman, 2020). In addition, while it is aimed to realize learning with traditional UE, it is aimed to continue teaching activities with EDE carried out during the pandemic process and to keep students from the process. According to many researchers, this is; It is an alternative, temporary teaching method developed in response to a specific crisis situation (Shim \& Lee, 2020). The first purpose in this process is to create immediate-temporary solutions to disrupted educational activities (Hodges et al., 2020). These immediate-temporary solutions can be expressed as a reflex of bringing together teachers and learners quickly with the help of various online tools. 
With this study; In the EDE process, which was implemented in a mandatory and sudden manner with the Covid-19 Pandemic, to collect information on the opinions of academics teaching in education faculties about DE/EDE and distance teacher training (DTT), EDE practices, problems they encountered in this process and suggestions for solutions. intended.

\section{Method}

In this study, the case study model, one of the qualitative research methods, was used. The study group of the research consists of 10 academicians working in the education faculties of various universities and continuing their education in the EDE process. While determining the participants of this study in line with the purpose of the research and subproblems;

- Working in education faculties,

- Continuing education with EDE during the pandemic process,

criteria are based.

The research was conducted with semi-structured interview technique. The data were obtained with the data collection tool developed by the researcher. Descriptive analysis and content analysis were used in the analysis of the data obtained within the scope of the study.

\section{Findings}

When the data is examined; It can be deduced that academics are familiar with information technologies, they have benefited from these technologies before the pandemic, but this is mostly limited to computers. Considering the responses received, it may be possible to say that the previous DE experiences of the interviewed academics were insufficient. In addition, almost all of these academics did not receive any training on DE before or after the pandemic. All these may lead to the conclusion that there are deficiencies in the DE readiness of the academicians.

Problems faced by academics in EDE are discussed under five different themes. In the theme of "Technological Infrastructure and Problems of Competence"; Codes of "inadequacy in academician technological readiness”, “connection problems” and "inability to access technology" stand out. "Limited interaction" in the "Communication / Interaction Problems" theme and "Lack of motivation" in the "Teaching Process Problems" theme were the most repetitive codes. In addition, it is seen that some codes are formed in the themes of "Administrative Problems" and "Other Problems". 
The most frequently repeated codes in the solution suggestions brought by the academicians to the problems encountered in DE are; "Technological tool support / providing equal use opportunities”, “providing in-service training to academicians”, "reducing class sizes” and "obliging students to open cameras".

“What are the views of academics on DTT?” In order to collect data on the problem of "What are your views on DTT in the context of the nature of the teaching profession, the importance of teacher training and the distance education given during the Covid-19 pandemic?" question was posed. When the views of the academicians on DTT are examined, it is seen that negative opinions are more common. There are also positive and neutral opinions.

\section{Discussion and Conclusion}

At the end of the study, it was revealed that the participants generally did not give lectures through DE before the pandemic and almost all of these participants did not receive any training on DE. It was observed that all of the participants used computers in the technological elements they benefited from in the pre-pandemic teaching processes, but this use was generally limited to office programs to make presentations in the teaching processes. It is noteworthy that there are no answers such as LMS, e-mail, cloud storage, video conferencing applications. This situation can be associated with the low level of technological literacy. When all these are taken together, it can be interpreted that the academicians who teach in education faculties have very limited DE experiences and their readiness for EDE is not at a sufficient level. In a study examining the EDE practices of higher education institutions in Turkey during the pandemic period, it was reported that very few of the instructors received training for DE and this could cause various problems (Yavuz et al., 2020). Since academicians are in the service process, these deficiencies can only be eliminated with in-service training. In this context, it can be recommended to plan activities that can increase technological literacy and readiness for academics by YÖK and universities, especially during the EDE process that started with the pandemic.

Another result obtained from the study is that academicians faced many problems in the EDE process. These problems are examined in five groups: "Technological Infrastructure and Competence Issues”, “Communication / Interaction Issues”, “Teaching Process Issues”, “Administrative Issues” and “Other Issues”.

In line with the third sub-problem of the research, the academicians were asked to suggest solutions to the problems encountered in the EDE process. Considering the total 
number of codes, it is difficult to say that the participants are very productive in this regard. When the suggestions are examined, it is seen that the most repetitive statements are "Technological tool support / Ensuring equal use opportunities", "In-service training for academicians", "Reducing class sizes" and "obliging students to open cameras". When the answers given are considered holistically, it can be stated that the solution proposals generally aim to increase participation in classes, strengthen communication/interaction, and advance technological readiness.

When the last sub-problem of the research, the opinions of the academicians on DTT, was taken into consideration, some positive, negative and neutral opinions emerged. These views are generally seen to be negative. While neutral opinions are generally stated as that EDE has no effect on the teacher training process, some positive opinions are; It was stated that "this process was an opportunity for teacher candidates to learn distance education" and "distance education should be in teacher education". In a similar study conducted with preservice teachers, the novice teachers positively characterized the testing of EDE in this process and the determination of its faults (Görgülü Ar1 \& No Kanat, 2020). Therefore, in order to turn this crisis situation into an opportunity, it can be argued that a transformation in teacher education should be made today (Sezgin, 2021). In this context, especially in teacher training programs, elective courses including applications for DE can be given.

Despite all these views on DTT, there are many negative views. These views of academics; They stated with statements such as "Internship / applied courses are missing, this is a problem", "I think the process harms teacher training", "I think it is not possible to become a teacher with distance education". Considering the fact that teaching is an applied field, the problems encountered in the process and the limitations of EDE, it is possible to say that the EDE process harms teacher education. With the measures that can be taken, this damage can be reduced to a certain extent. It can be suggested to conduct a different study on a sample of teacher candidates and to examine the views of prospective teachers, who are another stakeholder of the process, on the EDE and DTT process. 